MARCIN KIEDRZYŃSKI ${ }^{1}$, KATARZYNA ZIELIŃSKA ${ }^{2} \&$ PAULINA GRZELAK $^{3}$

Department of Geobotany and Plant Ecology, University of Lodz, Banacha 12/16 Str., 90-237 Lodz, e-mail: ${ }^{1}$ kiedmar@biol.uni.lodz.pl, ${ }^{2}$ kziel@biol.uni.lodz.pl, ${ }^{3}$ p.grzelak11@wp.pl

\title{
TRANSFORMATION OF FOREST VEGETATION AFTER 40 YEARS OF PROTECTION IN THE TOMCZYCE NATURE RESERVE (CENTRAL POLAND)
}

\begin{abstract}
The Tomczyce nature reserve is characterized by a degenerated forest vegetation. We assume that the regeneration process was possible to launch after the establishment of the nature reserve in 1968. The vegetation of the Tomczyce forest complex was characterized for the first time by JAKUBOWSKA-GABARA (1976) whose studies were taken as a basis of our research. The phytocenoses after 40 . years of protection have a greater participation of species with higher trophic and moisture requirements. The regeneration process in communities with pine trees is caused by an expansion of broad-leaved trees and shrubs. Transformation of forest vegetation causes a decrease in cover of thermophilous and heliophilous species. On the other hand, species of oak-hornbeam forests as well as anthropophytes are in expansion. Planning of the protection activities in the nature reserve needs to include these dynamic tendencies of the vegetation.
\end{abstract}

Key words: forest regeneration, mixed pine-oak forest, nature protection, Central Poland

\section{INTRODUCTION}

Natural forest communities develop in cycles which particular phases differ considerably from each other (KoOP 1989; OLIVER, LARSON 1996). The 
developmental phases, connected with the dynamics of small gaps, occurred in primeval lowland forests of Europe (PiCKETT, White 1985; Mitchell 2005; MoORE 2005). These forest communities were also formed by quite extensive and large natural disturbances. However, in European lowland forests, they usually did not occur in the same spatial scale or in constant intensity (SZWAGRZYK 2000).

The present forest landscape is predominantly formed by anthropogenic disturbances which not only result in impoverishment of the dynamic structure of communities but also in changes in habitat conditions and species composition of forest stands (ELLENBERG 1988). Forest management in Europe, lasting for many centuries, has resulted in the development and existence of specific plant communities. Anthropopressure as an ecological factor has caused the formation of substitute communities representing different phases and forms of degeneration (FALIŃSKI 1966; OLACZEK 1972). The abandonment of the old ways of forest use observed in the last several decades and the implementation of the ecological silviculture have brought about spontaneous regeneration of forest communities, that in turn led to their renaturalization (DZIEWOLSKI 1991; SzWAGRZYK 1996; KUROWSKI 2004 a; ŁASKA 2006).

Protected areas are useful objects for studying such spontaneous regeneration because human activity is limited or restricted there. Moreover, the vegetation in nature reserves and national parks was studied in the past. Due to these basic studies, these areas are convenient research objects (SzWAGRZYK 1994; HERBICH 1999; PAWLACZYK 1999; HOLEKSA 2005; MATUSZKIEWICZ 2007). Registration of changes in nature reserves puts forward information about the undergoing processes after limitation of anthropopressure, as well as about the transformations of natural environment. It also proves useful while verifying the targets and methods of protection (SzWAGRZYK 1994; OlaCZeK, KuRZaC 1995; PAWLACZYK 1999). The transformation of forest communities in protected areas has been studied by many researchers in Poland (FALIŃSKI 1986; JAKUBOWSKA-GABARA 1995; KUROWSKI 2004 b; HoleKsa, SZWAGRZYK 2006; MATUSZKIEWICZ 2007; BRZEZIECKI 2008 and others). Changes in prominently anthropogenic phytocenoses are among important aspects of regeneration of forest communities (OLACZEK 1998; FALIŃSKI 2000). 
Most of the protected areas were established to preserve quite natural phytocenoses. In other cases, where landscape, geological, geomorphologic or zoological values are the main conservation objectives, plant communities may have more anthropogenic character.

The Tomczyce nature reserve was established for the protection of specific geomorphological forms on the valley-side of the Pilica River and the old pine-stand - characterized by strongly transformed vegetation (JAKUBOWSKA-GABARA 1976). The Tomczyce nature reserve is situated in the south-eastern part of Central European Lowland, in the physico-geographical region of the Białobrzegi Valley, which includes the lower part of the Pilica River valley - the left-side tributary of the Vistula River (KONDRACKI 2002). According to the regional geobotanical division, it is located in the Great Valleys Zone in the southern part of the Masovian Region, in the district of Rawa (SZAFER, ZARZYCKI 1977).

The investigated forest complex is situated on a steep slope of the Pilica River valley and includes the high plain as well as a narrow strip of the floodplain. The valley-side is cut through by many deep flat-bottomed accumulation valleys directing to the river (Fig. 1). Both the occurrence of such landforms and the location on the slope contribute to a great variety of topography (GRABDA 1935; JAKUBOWSKA-GABARA 1976). The small forest complex, which includes the Tomczyce nature reserve, borders the Tomczyce village and the old manor dating from the middle of the $19^{\text {th }}$ century. It is supposed that part of this forest area was used as a manor park in the past. There is a share of some planted alien species in the studied phytocenoses. We assume that the regeneration process started in 1968 after the establishment of the nature reserve in the area of 57.99 ha.

The aim of this study was to investigate the present state of the vegetation, directions and the rate of its changes during last 40 years after cessation of the forest use and in relation to its initial state. The vegetation of the Tomczyce forest complex was characterized by JAKUBOWSKA-GABARA (1976) whose results were taken as a reference point in this study. 


\section{MATERIALS AND METHODS}

\section{Results of the Jakubowska-Gabara's studies (1976)}

Jakubowska-Gabara studied the vegetation of the Tomczyce forest complex in 1971-1973 (JAKUBOWSKA-GABARA 1976). Her attention was drawn to many old pine trees occurring in the nature reserve which were over 100 years old. These trees were very characteristic with their much-branched and curved boughs. High plain, slopes and upper parts of the flat-bottomed accumulation valleys were occupied by phytocenoses of Querco roboris-Pinetum and Pinus sylvestris xerothermic community of uncertain syntaxonomic affiliation. Flat bottoms of the accumulation valleys and their slopes were covered by small patches of Tilio-Carpinetum typicum. A small part of the floodplain was occupied by phytocenoses of Fraxino-Alnetum.

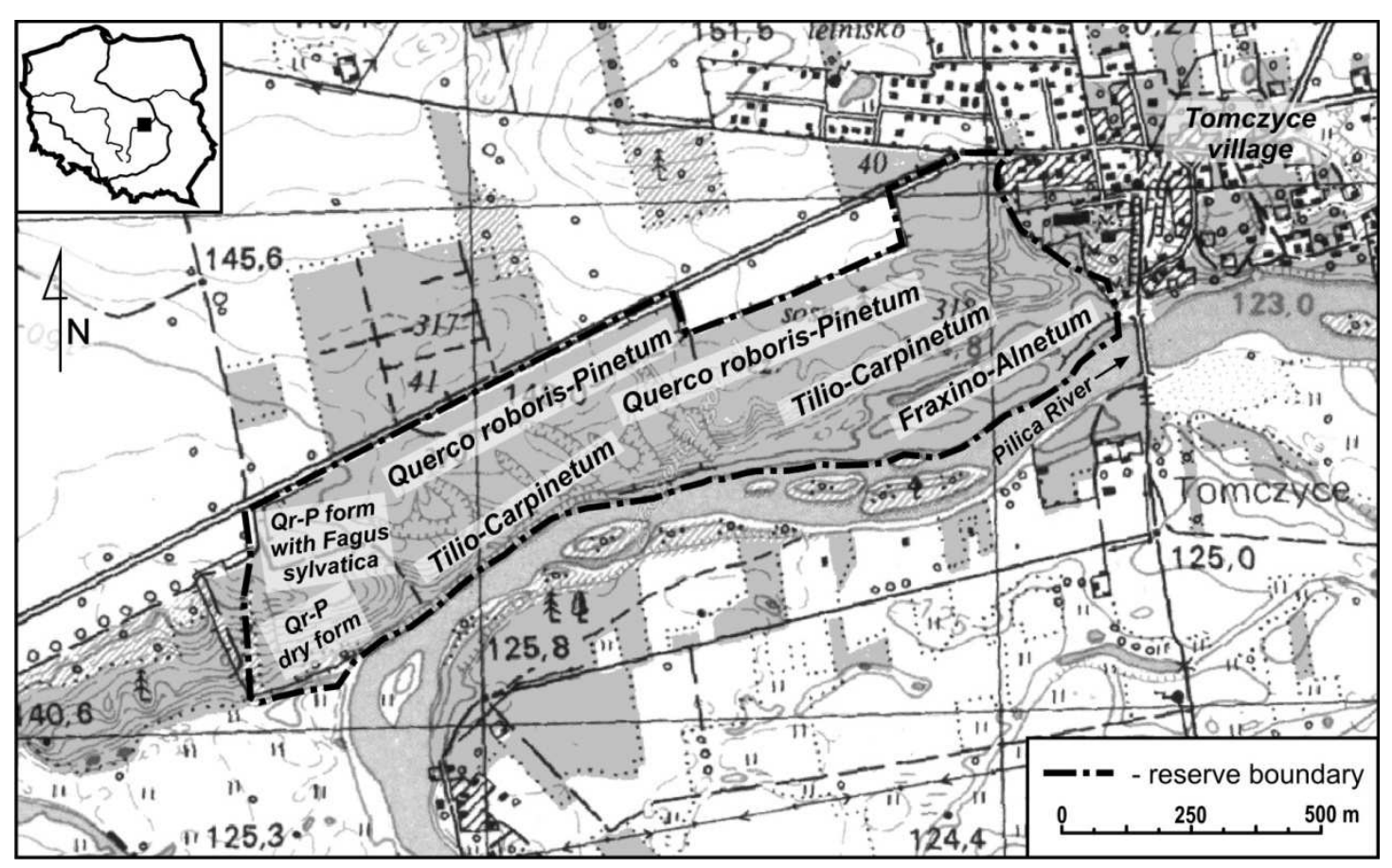

Fig. 1. Location of the Tomczyce nature reserve (based on the topographic map; scale: 1:25000, national coordinate system "1965") and distribution of the main forest associations in 2008 . 
The phytocenoses of Querco roboris-Pinetum were characterized by a domination of Pinus sylvestris in tree stands which were mainly planted in the studied area. Due to the characteristic crown shape of pine trees we cannot exclude that some of them could grow spontaneously in the deforested area. Moreover, Betula pendula was a common component of the forest stands. The understorey layer was well-developed and rich in species. The upgrowth of Quercus robur was the most frequent. Juniperus communis, Corylus avellana and Padus serotina was also present. The herb layer was mainly composed of: Vaccinium myrtillus, Melampyrum pratense, Festuca ovina. The presence of species from VaccinioPiceetea class and the domination of Pinus sylvestris indicated that phytocenoses had an acidophilic character.

The xerothermic community with Pinus sylvestris occurred on steep slopes of the Pilica River valley in the southern part of the nature reserve. The forest stand was a monoculture of 70 years old pine trees. The understorey layer was poorly developed with some upgrowths of Quercus robur, Juniperus communis and Sorbus aucuparia. The sparsely developed herb layer consisted of species from different syntaxonomic groups with participation of xerothermic and heathland species. The participation of species from Koelerion glaucae alliance (Koelerio-Corynephoretea class) characterized this community. The moss layer was well-developed.

In patches of Fraxino-Alnetum, about 40 years old Alnus glutinosa tree stands occurred. The understorey layer was fully-stocked and rich in species. It was mainly Padus avium and Euonymus europaea, Sambucus nigra or Fraxinus excelsior. A neophyte, Acer negundo, was quite frequent. The abundant herb layer was dominated by species from Querco-Fagetea and Molinio-Arrhenatheretea classes. Stellaria nemorum, Galium aparine, Glechoma hederacea and Poa trivialis had the greatest coverage in the ground layer.

To document the variety of plant communities in the nature reserve, JAKUBOWSKA-GABARA (1976) made 12 phytosociological relevés with the standardized phytosociological method (PAWŁOWSKI 1977; DZWONKO 2007). These plots were located in places which were homogeneous and representative for the communities occurring in the nature reserve. Only the phytocenoses of Tilio- 
Carpinetum were discounted by the authoress because of their excessive fragmentation. The location of the phytosociological relevés was given in the paper of JAKUBOWSKA-GABARA (1976) by putting the numbers of forest compartments.

\section{Field studies in 2008}

The studies of Jakubowska-Gabara were repeated in 2008 with the use of the same method. By penetrating the nature reserve, the variety of vegetation was evaluated. 13 phytosociological relevés were made to document the whole variety of vegetation. It was unachievable to situate the plots exactly in the same places as in the past. However, where it was possible, the most probable locations of the relevés from 1970s had been trying to be found. It was made on a basis of an analysis of the historical and actual composition of the forest stands. The locations of the repeated phytosociological relevés were marked on trees during the field work as well as the geographic coordinates of the centre points of the plots were noted. The coordinates (WGS 84) of the relevés for the following syntaxa are: Querco roboris-Pinetum dry

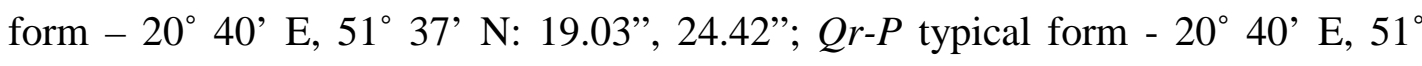
37’N: 38.50”, 35.67”; 53.28”, 39.43”; 55.46”, 42.06; 2041' E, 51 37' N: 3.71”, 41.34"; 9.30", 41.35"; 18.36", 43.03"; Qr-P form with Fagus sylvatica - 2040' E, 51 37’N: 19.88”, 30.77”; Fraxino-Alnetum - 2041' E, 51 37' N: 31.26”, 40.18”; 20.44”, 37.43"; Tilio-Carpinetum - 2040’ E, 51 37' N: 38.60”, 31.42”; 49.84”, $34.55 ” ; 20^{\circ} 41^{\prime} 21.51^{\prime \prime} \mathrm{E}, 51^{\circ} 37^{\prime} 40.26^{\prime \prime} \mathrm{N}$.

\section{Methods of the data's analysis}

The present variety of the forest vegetation in the nature reserve was compared with the historical vegetation from 1970s. The comparison and analysis was made with the Juice 7.0 and R 2.9.0 programme (TICHÝ, HOLT 2006; ZELENÝ, TICHÝ 2006). Phytosociological tables were prepared and plant associations were named. The syntaxonomic affiliation of species is given according to MAtuszKIEwiCZ (2001). The Detrended Correspondence Analysis (DCA) of the actual and historical phytosociological relevés was done in order to support the classification of the distinguished plant associations (HILL, GAUCH 1980). The 
indirect gradient analysis based on the DCA ordination according to the gradients which are responsible for the ecological variability of the flora's composition was adopted, too. This method is based on the analysis of relevés in the ordination diagram according to habitat factors which were estimated with the use of the ecological numbers according to ELLENBERG et al. (1992).

The analysis of changes in the species composition was made for the best documented community which is Querco roboris-Pinetum. Seven phytosociological relevés of JAKUBOWSKA-GABARA (1976) and seven relevés from the present studies (the form with Fagus sylvatica was discounted only) were used. The analysis was based on the average cover of chosen species and syntaxonomic groups in the community. The average species' cover was calculated with the Barkman's formula (1989). The nomenclature of species is given according to MIREK et al. (2002) and the nomenclature of plant association according to MATUSZKIEWICZ (2001).

\section{RESULTS}

\subsection{Changes of the syntaxa in time}

The historical and present vegetation in the nature reserve is divided into four main syntaxa. These are three associations (Querco roboris-Pinetum, TilioCarpinetum and Fraxino-Alnetum) and one community (Pinus sylvestris xerothermic community) of an uncertain phytosociological position (Tab. 1, Fig. 2).

Any phytocenoses which could be classified as the xerothermic community with Pinus sylvestris from 70s were found in the Tomczyce nature reserve in 2008. In present studies, three forms of the mixed forest Querco roboris-Pinetum: typical, dry and form with Fagus sylvatica were found (Tab. 1, Fig. 2). The TilioCarpinetum oak-hornbeam forest is a community, which undergoes a regeneration. Its fragments with a patchy herb layer were described in 70 s but without any phytosociological relevés. After 40 years of protection, due to the regeneration of the oak-hornbeam forests occurring at the flat bottoms and slopes of the accumulation valleys, we were able to collect three phytosociological relevés. 
Table 1. Forest vegetation syntaxa in the Tomczyce nature reserve. Numbers of the vegetation units are same as in Figure 2.

1971-1973

(JAKUBOWSKA-GABARA 1976)

2008

\begin{tabular}{lc}
\hline $\begin{array}{l}1 \text { - Pinus sylvestris xerothermic } \\
\text { community }\end{array}$ & \\
\hline 2 - Querco roboris-Pinetum & Querco roboris-Pinetum \\
(most patches were similar to dry & 3 - dry form \\
form from 2008) & - typical form \\
& 5 - form with Fagus sylvatica \\
\hline 6 - Fraxino-Alnetum & 7 - Fraxino-Alnetum \\
\hline Tilio-Carpinetum - fragmentarily & 8 - Tilio-Carpinetum, regenerative \\
developed (information only from & form \\
the text, lack of relevés from the & \\
Tomczyce nature reserve) & \\
\hline
\end{tabular}

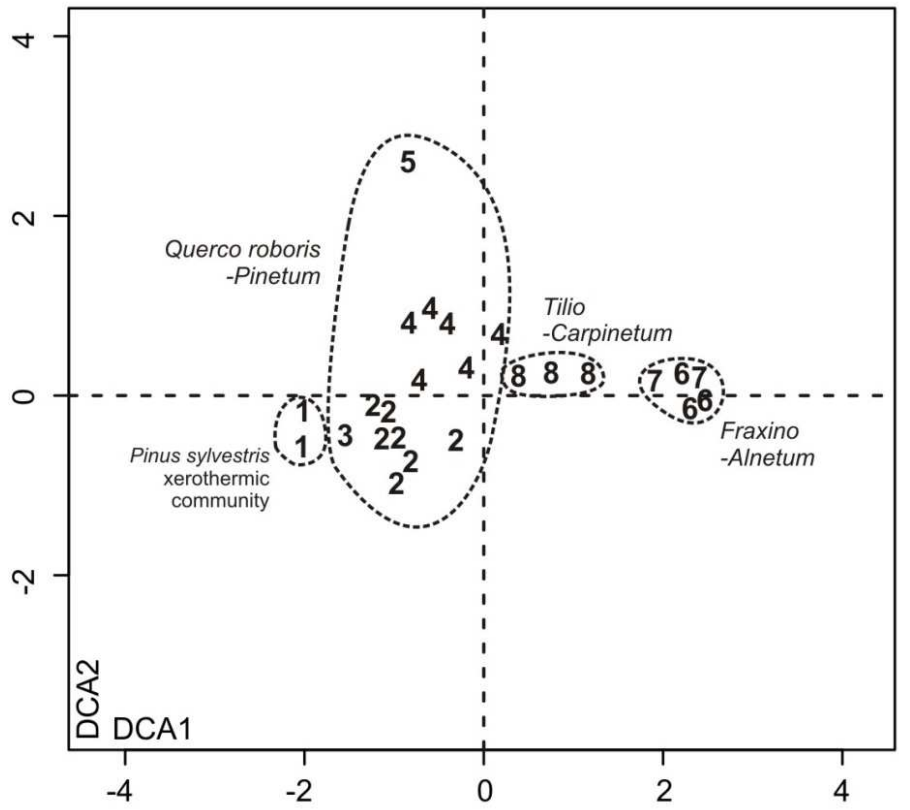

Fig. 2. DCA ordination of phytosociological relevés recorded in the Tomczyce nature reserve in 1970s and 2008. 1- Pinus sylvestris xerothermic community (197173), 2 - Querco roboris-Pinetum (1971-73), 3 - Qr-P dry form (2008), 4 - Qr-P typical form (2008), 5 - Qr-P form with Fagus sylvatica (2008), 6 - FraxinoAlnetum (1971-73), 7 - F-A (2008), 8 - Tilio-Carpinetum (2008). 
Generally, the vegetation of the Tomczyce nature reserve in 2008 was represented by patches with a greater share of species with higher trophic and moisture requirements than in the 1970s. The phytocenoses 40. years ago were composed of species which required more light and higher temperature (Fig. 3). The disappearance of Pinus sylvestris xerothermic community and emergence of the oakhornbeam forests in the phytosociological material is an effect of the indicated changes.

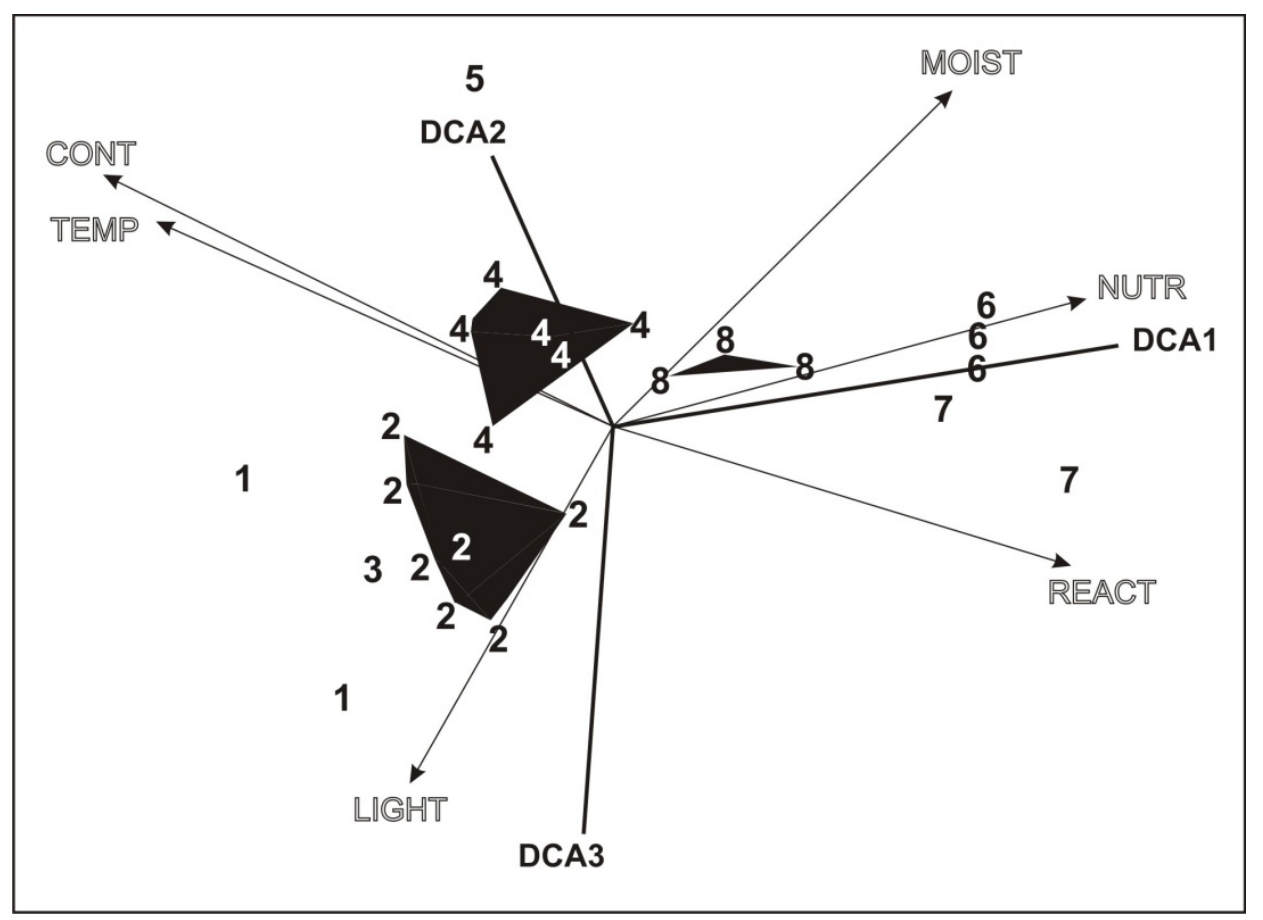

Fig. 3. DCA indirect gradient analysis of the vegetation in the Tomczyce nature reserve - based on Ellenberg indicator values. CONT - continentalism, TEMP temperature, MOIST - moisture, NUTR - nutrients, REACT - reaction. For numbers of the vegetation units see Figure 2.

\subsection{Changes in the floristic composition of the mixed oak-pine forest}

The composition of species in the mixed oak-pine forest does not differ much between 1970s and 2008. These two groups of relevés are located closely in the ordination diagram (Fig. 2). Especially, a patch of the "dry form" (3) from 2008 is similar to relevés from 1970s. It is a specific "relict" of the historical vegetation in 
this nature reserve. The form with Fagus sylvatica (5) found in 2008 was considerably different from the historical and present Querco roboris-Pinetum phytocoenoses. That was the reason why this single, different patch was not taken for the following analysis.

After 40 years of protection, the phytocenoses of mixed oak-pine forests have a greater participation of species with higher trophic and moisture requirements (Fig. 3). It is visible as an increased participation of species characteristic for Querco-Fagetea class (the average cover index changed from 9.0 to 22.1 - Tab. 2). A spontaneous change in domination of main tree species has occurred in the Tomczyce nature reserve. In comparison to 1970s, the expansion of broad-leaved trees and shrubs has taken place. The Querco roboris-Pinetum phytocenoses in 2008 had a greater participation of oaks Quercus robur and Q. petraea, trees and shrubs characteristic for Querco-Fagetea class - particularly hazel Corylus avellana. The pine tree Pinus sylvestris and the juniper Juniperus communis are less stocked.

Table 2. Changes of the average cover (Barkman`s index) of phytosociological classes in the Querco roboris-Pinetum phytocoenoses in the Tomczyce nature reserve. Phytosociological classes: V-P - Vaccinio-Piceetea. K-C - KoelerioCorynephoretea, $N-C$-Nardo-Callunetea, $M-A-M o l i n i o-A r r h e n a t h e r e t e a$, Epil. Epilobietea, T-G - Trifolio-Geranietea, F-B - Festuco-Brometea, Q-F - QuercoFagetea, Artem. - Artemisietea, Stel. - Stellarietea, Agrop. - Agropyretea.

\begin{tabular}{lcc} 
& $1971-73(\mathrm{n}=7)$ & $2008(\mathrm{n}=7)$ \\
\cline { 2 - 3 } $\begin{array}{l}\text { Phytosociological } \\
\text { classes }\end{array}$ & $\begin{array}{c}\text { Average cover } \\
\pm \text { SD }\end{array}$ & $\begin{array}{c}\text { Average cover } \\
\pm \text { SD }\end{array}$ \\
\hline$V-P$ & $98.8 \pm 44.2$ & $86.3 \pm 35.2$ \\
$K-C$ & $21.0 \pm 11.0$ & $4.3 \pm 6.1$ \\
$N-C$ & $15.0 \pm 5.8$ & $6.3 \pm 9.3$ \\
$M-A$ & $8.4 \pm 9.3$ & $1.1 \pm 3.0$ \\
Epil. & $6.1 \pm 6.8$ & $2.3 \pm 2.1$ \\
$T-G, F-B$ & $3.8 \pm 4.8$ & $\nabla$ \\
\hline - $F$ & $7.2 \pm 6.5$ & $\mathbf{\nabla}$ \\
Artem., Stel., Agrop. & $5.1 \pm 4.2$ & $22.1 \pm 19.8$ \\
$R-P$ & $1.0 \pm 2.0$ & $8.6 \pm 16.2$ \\
\hline
\end{tabular}


The mixed oak-pine forests in 2008 were characterized by a smaller share of plants which are typical for open communities with more light (Fig. 2). There were a smaller participation of grassland and meadow species characteristic for KoelerioCorynephoretea, Nardo-Callunetea and Molinio-Arrhenatheretea classes (Tab. 2).

In 2008 mixed oak-pine forests had a greater share of kenophytes (Tab. 3). Trees and shrubs such as: Padus serotina, Quercus rubra and Amelanchiaer sp., probably planted in the past, are now spontaneously self-seeding and have appeared in higher forest layers (Tab. 3).

Table 3. Changes of the average cover (Barkman`s index) of kenophytes in the Querco roboris-Pinetum phytocoenoses in the Tomczyce nature reserve.

\begin{tabular}{|c|c|c|c|}
\hline & $1971-73(n=7)$ & & $2008(n=7)$ \\
\hline Species name & $\begin{array}{c}\text { Average cover } \\
\pm \mathrm{SD}\end{array}$ & & $\begin{array}{c}\text { Average cover } \\
\pm \mathrm{SD}\end{array}$ \\
\hline Aesculus hippocastanum [c] & $0.3 \pm 0.8$ & $\nabla$ & 0.0 \\
\hline Padus serotina $[\mathrm{a}+\mathrm{b}+\mathrm{c}]$ & $3.6 \pm 5.9$ & $\Delta$ & $20.3 \pm 15.3$ \\
\hline Amelanchier sp. $[\mathrm{b}+\mathrm{c}]$ & $1.4 \pm 2.4$ & & $15.1 \pm 27.3$ \\
\hline Quercus rubra $[\mathrm{a}+\mathrm{b}+\mathrm{c}]$ & $1.0 \pm 1.9$ & & $2.4 \pm 2.4$ \\
\hline Impatiens parviflora & 0.0 & & $6.4 \pm 14.0$ \\
\hline Prunus cerasifera $[\mathrm{c}]$ & 0.0 & & $0.6 \pm 1.0$ \\
\hline Conyza canadensis & 0.0 & & $0.3 \pm 0.8$ \\
\hline Malus domestica [c] & 0.0 & & $0.3 \pm 0.8$ \\
\hline All kenophytes & $6.3 \pm 6.0$ & & $45.4 \pm 40.1$ \\
\hline
\end{tabular}

\section{DISCUSSION}

Vegetation changes which have occurred in the Tomczyce nature reserve reveal a general tendency of fertilization which take place in Polish and European forests. In the case presented here, the effect of these changes, indicating the habitat fertilization, is the transformation of communities from coniferous forests to mixed forests and the mixed oak-pine forests to oak-hornbeam forests.

One of the main mechanisms initiating the regeneration or succession processes in forest communities with pine trees plantations is an expansion of broadleaved trees and shrubs (OlaCZEK 1974; CZEREPKo 2001; KUROWSKI 2004 a, 
KIEDRZYŃSKI 2008). The development of dense tree stands and undergrowth is an effect of a luxuriant growth of oaks, hornbeams, maples, lindens and shrubs of hazel under pine trees. That in turn causes a limitation of light reaching the forest ground and litter enrichment in quickly decomposing biomass. Such changes can be observed in the Tomczyce nature reserve, particularly in the mixed oak-pine forests. This process is the fastest in the flat-bottomed accumulation valleys and on steep and shady slopes, and slower on gentle, dry and sandy slopes as well as in the high plain. Similar changes were observed in the Babsk nature reserve by OLACZEK and KURZAC (1995) after 30 years of protection. The transformation of coniferous forests was also described by KUROWSKI (2004 b) from the Jaksonek nature reserve near the Pilica River where particular dynamics of hazel and oaks was observed. The author described the transformation of mixed oak-pine forests into oak-hornbeam forests and fresh pine forests into mixed oak-pine forests.

Other studies on dynamics of phytocenoses of Querco roboris-Pinetum and Tilio-Carpinetum in Białowieża National Park indicated great dynamic changes described as a substitution of birches, pine trees, spruces and oaks with lindens and hornbeams (BRZEZIECKI 2008). The habitat fertilization was also observed by KOWALSKI (1994), BERNADZKI et al. (1998), BRZEZIECKI (1999) and PALUCH (2001). Changes of microclimatic and habitat conditions following the development of trees and broad-leaved shrubs in the Tomczyce nature reserve - as well as in the quoted research - have led to a greater cover of species characteristic for mesophilous forests with higher trophic and moisture requirements.

The expansion of oaks is significant in natural restructuring of forest stands in the study site. Similar processes are observed in numerous areas in the whole lowland part of Europe (KIENAST 1991). Oaks often build layers under pine stands and this spontaneous process is sometimes used in silviculture as well. Dynamic restocking of oaks occurs in the regeneration process of phytocenoses under the influence of planted pine trees on more fertile habitats (OLACZEK 1972; CZEREPKO 2001; KUROWSKI 2004 a; ŁASKA 2006) or during vegetation succession (inter alia BomanowsKa, ADAMOWSKi 2009). Both of these processes may take place in the Tomczyce nature reserve due to the probable partial deforestation of the studied 
area. A few oaks, which are about 150 years old and have been preserved in the nature reserve, are the sources of diaspores. In most cases, the expansion of oaks takes place with the use of birds (jays) which spread acorns (DANIELEWICZ, PAWLACZYK 2006).

Some authors connect the appearance of species characteristic for more fertile habitats with general changes in environmental conditions leading in turn to habitat fertilization. It is said that the main factors responsible for that are the climate warming and ambient concentration of nitrogen compounds (inter alia BRZEZIECKI 2008; KowALSKI 1994). We cannot exclude that the processes of vegetation transformation in the Tomczyce nature reserve are also under the influence of general factors and the observed fertilization can be accelerated by them.

Encroachment of broad-leaved tree species and habitat fertilization cause often a decline in thermophilous and heliophilous species which occurrence may be connected with management of forests in the past (MATUSZKIEWICZ 2007) or an early stage of forest succession (Dölle et al. 2008). The disappearance of Pinus sylvestris xerothermic community and retreating of grass, heathland and meadow species from other communities was observed in the studied area. Similar tendencies are the cause of disappearance of some communities from Polish forest landscape, such as thermophilous oak forest Potentillo albae-Quercetum, subboreal mixed forest Serratulo-Pinetum and pine forests with pasque-flowers Peucedano-Pinetum pulsatilletosum (JAKUBOWSKA-GABARA 1993; SOLON 2007; SZCZYGIELSKI 2007). In Polish conditions, retreating of heliophilous species occurs most often in protected areas where forest management was ceased (MATUSZKIEWICZ 2007).

The present studies has revealed a greater participation of anthropophytes than in former studies in the Tomczyce nature reserve. The presence of such tree and shrub species as Amelanchiaer sp., Padus serotina and Quercus rubra is also in line with the trend of increasing participation of broad-leaved species in the communities. A higher cover and moving to higher layers of forest phytocoenoses confirm that described species have found here favorable habitats. Their participation modifies the regeneration process and their relatively fast growth 
probably accelerates it. The former management of the studied area, leading to a greater importance of Pinus sylvestris, was conducive to neophytization. In the Białowieża Primeval Forest the greatest numbers of alien species with the largest populations were found in oak-hornbeam forest habitats under pine plantations (ADAMOWSKI et al. 1998). Many authors have indicated that Padus serotina and Quercus rubra are the cause of communities' degeneration and reduction of species richness (HEREŹNIAK 1992; TOBISCH et al. 2003; GODEFROID et al. 2005; OTRĘBA, FERCHMIN 2007; JAKUBOWSKA-GABARA, WOZIWODA 2009). Impatiens parviflora is also a threat because its range in the nature reserve has increased significantly. It has been proved that Impatiens parviflora after entering a community initially enriches the species composition but subsequently it exerts a reductive influence on other elements of the herb layer (KuJAWA-PAWLACZYK 1991; ORCZEWSKA 2000). A large number of alien species is associated with habitat transformation and community degeneration (ADAMOWSKI et al. 1998; WOZIWODA 2007), therefore, we can forecast that the presence of alien species in the Tomczyce nature reserve may be a factor which finally will inhibit the regeneration of forest phytocoenoses. The occurrence of the planted Fagus silvatica in a higher located part of the nature reserve can have a significant role for the vegetation that will form here in the future. Many authors observed a reduction in flora's diversity in the phytocenoses of mixed oak-pine forests and thermophilous oak forests with planted Fagus sylvatica (OlaCZEK, KURZAC 1995; DANIELEWICZ, PAWLACZYK 2006; KIEDRZYŃSKI 2008).

Vegetation changes had undoubtedly an influence on the impoverishment of flora in the Tomczyce nature reserve. Some valuable heliophilous species have decreased their abundance. On the other hand, species of oak-hornbeam forests are in expansion. Planning of protection activities needs to include dynamic tendencies of vegetation. These tendencies can be used in the pursuit and revision of the chosen targets or we can try to stop them, however, we have to take them into consideration (PAWLACZYK 1999). The present state of vegetation cover in the Tomczyce nature reserve and the necessity of preserving the forest vegetation on steep slopes of flatbottomed accumulation valleys and in the river valley should be of key importance while undertaking protection activities in the nature reserve. We may consider 
removing of Fagus sylvatica which is planted here outside its natural range and alien species from such places which would not endanger the stability of the slopes in the flat-bottomed accumulation valleys. A decision is to be made whether a passive observation of the regeneration changes may be of greater value in this case, taking into consideration the fact that in the meantime this may lead to an increased importance of neophytes in the nature reserve.

\section{CONCLUSIONS}

- The expansion of broad-leaved trees and shrubs, particularly oaks, is the main mechanism initiating transformation of the vegetation and caused disappearing the pine-xerotermic community from Tomczyce nature reserve.

- The encroachment of mesophilous forest species and the declining of thermophilous and heliophilous species is a symptom of mixed oak-pine and oak-hornbeam forests regeneration.

- Despite the probability of increasing participation of alien species in the nature reserve in the future, the passive protection and an observation of processes without interfering in the structure of forest stands needs to be taken into consideration.

\section{Acknowledgements}

The field research took place during the scientific camp of the Students' Science Club Botanical Section in the Faculty of Biology and Environmental Protection which was funded by the University of Lodz. Therefore, the authors would like to thank Adam Adamas, Aneta Drewnicz, Ilona Daraż, Ewelina Koczywąs, Michał Pieńkowski, Martyna Pychowska and Izabela Zając for taking part in the field work. Moreover, we are especially grateful to Grzegorz J. Wolski who denominated the species of bryophytes. 


\section{REFERENCES}

AdAMOWski, W., MęDrZYCKI, P., ŁUCZAJ Ł. 1998. The penetration of alien woody species into the plant communities of the Białowieża Forest: the role of biological properties and human activities. Phytocoenosis 10 (N.S.) Suppl. Cartogr. Geobot. 9: 211-228.

BARKMAN, J.J. 1989. A critical evaluation of minimum area concepts. Vegetatio 85: 89-104.

BernADZKi, E., BoliBoK, L., BrZEZIECKI, B., ZAJĄCZKOWSKI, J., ŻYBURA, H. 1998. Rozwój drzewostanów naturalnych Białowieskiego Parku Narodowego w okresie od 1936 do 1996 roku. SGGW, Warszawa.

Bomanowska, A., Adamowski, W. 2009. The role of woody species in the secondary succession under monitored conditions (Bialowieza Forest, NE Poland). In: D. Ivanova (ed.), Plant, fungal and habitat diversity investigation and conservation. Proceedings of IV Balkan Botanical Congress, Sofia, 20-26 June 2006. Institute of Botany, Bulgarian Academy of Sciences, Sofia, pp. 291295.

BRZEZIECKI, B. 1999. Wzrost żyzności siedlisk: zjawisko pozorne czy rzeczywiste? Sylwan 11: 99-107.

BRZEZIECKI, B. 2008. Wieloletnia dynamika drzewostanów naturalnych na przykładzie dwóch zbiorowisk leśnych Białowieskiego Parku Narodowego: PinoQuercetum i Tilio-Carpinetum. In: J. HolEKSA (ed.), Zakres, tempo i mechanizmy zmian w przyrodzie terenów chronionych w Polsce. Studia Nat. 54, cz. II: 9-22.

CzEREPKO, J. 2001. Spontaniczna regeneracja lasu grądowego z lasem sosnowym w Puszczy Białowieskiej jako metoda renaturyzacji. Przegląd Przyrodniczy 12 (34): 81-90.

DANIElewicz, W., PAWlaczyK, P. 2006. Rola dębów w strukturze i funkcjonowaniu fitocenoz. In: W. BugaŁA (ed.), Dęby. Nasze Drzewa Leśne 11. Instytut Dendrologii PAN, Poznań - Kórnik, pp. 474-564. 
Dölle, M., Bernhardt-Römermann, M., PARTh, A., SchmidT, W. 2008. Changes in life history trait composition during undisturbed old-field succession. Flora 203: 508-522.

DZIEWOLSKI, J. 1991. Kierunki przemian drzewostanów w parkach narodowych polskich Karpat w warunkach ochrony ścisłej i częściowej. Prądnik Pr. Muz. Szafera 4: 9-26.

DZWONKO, Z. 2007. Przewodnik do badań fitosocjologicznych. Instytut Botaniki Uniwersytetu Jagiellońskiego. Wydawnictwo Sorus. Poznań - Kraków.

Ellenberg, H., Weber, H. E., Düll, R., Wirth, W., Werner, W., Paulissen, D. 1992. Zeigerwerte von Pflanzen in Mitteleuropa. Ed. 2. Scripta Geobot. 18: 1258.

EllenberG, H. 1988. Vegetation Ecology of Central Europe. Cambridge University Press, Avon.

FALIŃSKI, J.B. 2000. The interpretation of contemporary vegetation transformations on the basis of the theories of synanthropisation and syndynamics. In: B. JACKOWIAK, W. ŻUKOWSKI (eds), Mechanisms of Anthropogenic Changes of the Plant Cover. Bogucki Wydawnictwo Naukowe, Poznań, pp. 9-30.

FALIŃSKI, J.B. 1966. Próba określenia zniekształceń fitocenozy. System faz degeneracyjnych zbiorowisk roślinnych. Dyskusje fitosocjologiczne (3). Tom XII: 31-43.

FALIŃSKI, J.B. 1986. Vegetation dynamics in temperate lowland primeval forests. Ecological studies in Białowieża Forest. Geobotany 8. Dr W. Junk Publishers, Dordrecht/Boston/Lancaster, pp. 1-537.

Godefroid, S., Phartyal, S.S., Weyembergh, G., Koedam, N. 2005. Ecological factors controlling the abundance of non-native invasive black cherry (Prunus serotina) in decidous forest understory in Belgium. Biol. Conserv. 210: 91-105.

GRABDA, E. 1935. Brzegi Pilicy pod Tomczycami. Ochr. Przyr., 15: 311-313.

HeRBICH, J. 1999. Plan ochrony, czyli coś jesteśmy winni przyrodzie. Przegl. Przyr. $10(1 / 2): 3-15$.

HeREźNIAK, J. 1992. Amerykańskie drzewa i krzewy na ziemiach polskich. In: M. ŁAWRYNOWICZ, A.U. WARChOLIŃSKA (eds), Rośliny pochodzenia 
amerykańskiego zadomowione w Polsce. Szlakami Nauki 19. Łódzkie Towarzystwo Naukowe, Łódź, pp. 97-150.

HILL, M.O., GAUCH, H.G. 1980. Detrended correspondence analysis an an improved ordination technique. Vegetatio 42: 47-58.

HolEKSA, J. 2005. Advantages and disadvantages of the strong position of phytosociology for nature conservation in Poland. Ecol. Questions 6: 19-27.

HoleKsa, J., SzWAGRZYK, J. 2006. Zakres, tempo i mechanizmy zmian w przyrodzie terenów chronionych w Polsce - wprowadzenie. In: J. HoLEKSA (ed.), Zakres, tempo i mechanizmy zmian w przyrodzie terenów chronionych w Polsce. Studia Nat. 54, cz. I: 7-11.

JaKubowska-Gabara, J. 1976. Zespoły leśne Uroczyska Tomczyce. Acta Univ. Lodz. Zesz. Nauk. Uniw. Łódzkiego. Nauki Mat.-Przyr. Ser. II, z. 2: 109-125.

JAKUBOwSKA-GABARA，J. 1993. Recesja zespołu świetlistej dąbrowy Potentillo albae-Queretum Libb. 1933 w Polsce. Wydawnictwo Uniwersytetu Łódzkiego, Łódź.

JAKUBOWSKA-GABARA, J. 1995. Szata roślinna rezerwatu „Półboru” oraz jej zmiany w ciągu dziesięciu lat. Acta Univ. Lodz., Folia sozol. 4: 93-122.

JAKUBOWSKA-GABARA, J., WozIWODA, B. 2009. Decrease of vascular flora diversity in forest communities connected with invasive Quercus rubra. In: "Vegetation Processes and Human Impact in a Changing World". Abstracts. 52 ${ }^{\text {nd }}$ International Symposium IAVS, Chania, Crete (Greece), May $30^{\text {th }}-4$ the June, p. 179.

KIEDRZYŃSKI, M. 2008. The impact of forest management on the flora and vegetation of old oak-stands (An example from The Spała Forests, central Poland). Nat. Conserv. 65: 51-62.

KIENAST, F. 1991. Simulated successional characteristic of manager and unmanaged low-elevation forest in central Europe. For. Ecol. Manage. 42 (1-2): 49-61.

KONDRACKI, J. 2002. Geografia regionalna Polski. Wydawnictwo Naukowe PWN, Warszawa.

Koop, H. 1989. Forest Dynamics. SILVI-STAR: a comprehensive monitoring system. Springer Verlag. Berlin. 
KowALSKI, M. 1994. Zmiany składu gatunkowego lasów na tle zmian klimatu w ostatnich dwóch stuleciach. Sylwan 9: 33-43.

KujaWA-PAWlaCZYK, J. 1991. Rozprzestrzenianie się i neofityzm Impatiens parviflora DC. w Puszczy Białowieskiej. Phytocoenosis 3 (N.S.) Sem. Geobot. 1: 213-222.

KUROWSKI, J.K. 2004a. La degeneration et regeneration des phytocenoses forestières: l'exemple de la Pologne Centrale. Natura Mosana 57 (3): 57-76.

KUROWSKI, J.K. 2004b. The problem of the naturalness of pine forest - case study Jaksonek nature reserve on the Pilica River. In: A. BrZEG, M. WoJTERSKA (eds), Coniferous forest vegetation - differentiation, dynamics and transformations. Wydawnictwo Naukowe Uniwersytetu A. Mickiewicza, Poznań, pp. 171-177.

ŁASKA, G. 2006. Tendencje dynamiczne zbiorowisk zastępczych w Puszczy Knyszyńskiej. Bogucki Wydawnictwo Naukowe, Poznań.

MatuszKiewicz, J.M. (ed.). 2007. Geobotaniczne rozpoznanie tendencji rozwojowych zbiorowisk leśnych w wybranych regionach Polski. Monografie IGiPZ PAN, 8: 1-980.

MatuszKiewiCZ, W. 2001. Przewodnik do oznaczania zbiorowisk roślinnych Polski. Wydawnictwo Naukowe PWN, Warszawa.

Mirek, Z., PięKOŚ-Mirkowa, H., Zając, A., ZająC, M. 2002. Flowering plants and pteridophytes of Poland - a checklist. In: Z. MIREK (ed.), Biodiversity of Poland 1. W. Szafer Insitute of Botany, Polish Academy of Sciences, Kraków.

MitChELl, F.J.G. 2005. How open were European primeval forest? Hypothesis testing using palaeoecological data. J. Ecol. 93: 168-177.

MoORE, P. D. 2005. Down to the woods yesterday. Nature 433: 588-589.

OlACZEK, R. 1972. Formy antropogenicznej degeneracji leśnych zbiorowisk roślinnych w krajobrazie rolniczym Polski Niżowej. Wydawnictwo Uniwersytetu Łódzkiego, Łódź.

OlaCZEK, R. 1974. Etapy pinetyzacji grądu. Phytocoenosis 3 (3/4): 201-214.

OLACZEK, R. 1998. The synanthropization of plant cover in the protected areas as a scientific and conservation problem. Phytocoenosis 10 (N.S.) Suppl. Cartogr. Geobot. 9: 275-279. 
OLACZEK, R., KURZAC, M. 1995. Zmiany we florze i roślinności rezerwatu lipowego „Babsk” po trzydziestu latach ochrony. Acta Univ. Lodz., Folia sozol. 4: 123144.

OlivieR, C.D., LARSON, B.C. 1996. Forest stand dynamics. John Wiley and Sons, New York.

OrczewsKa, A. 2000. Anthropogenic Changes in yhe Vegetation of Woodland Islands of the Głubczyce Plateau (Opole Voivodship). In: B. JACKOWIAK, W. ŻUKOWSKI (eds), Mechanisms of Anthropogenic changes of the plant cover. Publications of the Department of Plant Taxonomy of the Adam Mickiewicz University in Poznań, 10, pp. 225-234.

OtrębA, A., Ferchmin, M. 2007. Obce gatunki drzew miarą przekształcenia przyrody Kampinowskiego Parku Narodowego. In: D. ANDERWALD (ed.), Siedliska i gatunki wskaźnikowe w lasach, część 1. Studia i Materiały Centrum Edukacji Przyrodniczo-Leśnej R.9. Zesz. 2/3 (16): 234-244.

PALUCH, R. 2001. Zmiany zbiorowisk roślinnych i typów siedlisk w drzewostanach naturalnych Białowieskiego Parku Narodowego. Sylwan 145 (10): 73-81.

PAWLACZYK, P. 1999. Złośliwy chichot przyrody, czyli o niebezpieczeństwach planowania. Przegl. Przyr. 10 (1/2): 17-27.

PAWŁOWSKI, B. 1977. Skład i budowa zbiorowisk roślinnych oraz metody ich badania. In: W. SZAFER, K. ZARZYCKI (eds), Szata roślinna Polski. Tom 1. PWN, Warszawa, pp. 237-279.

PicketT, S.T.A., White, P.S. (eds). 1985. The ecology of natural disturbance and patch dynamics. Academic Press. New York.

PIELOU, E.C. 1975. Ecological diversity. John Wiley and Sons, Inc., New York, NY.

Sierka, E., Chmura, D. 2006. Przemiany zbiorowisk leśnych i ich znaczenie dla ochrony walorów przyrodniczych rezerwatu przyrody "Dolina Żabnika" (Wyżyna Śląska). Chrońmy Przyr. Ojcz. 62 (4): 85-93.

Solon, J. 2007. Przekształcenia borów sosnowych świeżych w Puszczy Augustowskiej. In: J.M. MATUSZKIEWICZ (ed.), Geobotaniczne rozpoznanie tendencji rozwojowych zbiorowisk leśnych w wybranych regionach Polski. PAN IG i PZ. Monografie 8, pp. 176-196. 
SPIECKer, H., MielikÄInen, K., KöHL, M., SkovsgaArd, J.P. (eds.). 1996. Growth Trends in European Forests; EFI Research Report No. 5. Springer. Berlin.

SzAfER, W., ZARZYCKI K. (eds). 1977. Szata roślinna Polski. Tom 2. PWN, Warszawa.

SZCZYGIELSKI, M. 2007. Zmiana charakterystyki subborealnego boru mieszanego (Serratulo-Pinetum) w Puszczy Piskiej. In: J.M. MAtuszKIEWICZ (ed.). Geobotaniczne rozpoznanie tendencji rozwojowych zbiorowisk leśnych w wybranych regionach Polski. PAN IG i PZ. Monografie 8, pp. 116-128.

SzWAGRZYK, J. 1994. Co nauka jest winna ochronie przyrody? Przegl. Przyr. 5 (3/4): 3-16.

SzWAGRZYK, J. 1996. Dynamika układów ekologicznych a wzorce naturalności. Przegl. Przyr. 7 (3/4): 29-40.

SZWAGRZYK, J. 2000. Rozległe naturalne zaburzenia w ekosystemch leśnych: ich zasięg, character i znaczenie dla dynamiki lasu. Wiad. ekol. 46(1): 3-19.

TichÝ, L., Holt, J. 2006. Juice - program for management, classification of ecological data. Program manual. Vegetation Science Group. Masaryk University. Brno.

Tobisch, T., Csontos, P., RÉDeI, K., FüHrer, E. 2003. Fehér akác (Robinia pseudoacacia L.) faállományok vizsgálata aljnövényzetük összetétele alapján. Tájökológiai Lapok 1(2): 139-202.

WozIwODA, B. 2007. Identyfikacja i ocena stanu zachowania siedlisk grądowych (kod Natura 2000: 9170) w lasach Polski Środkowej. In: D. ANDERWALD (ed.), Siedliska i gatunki wskaźnikowe w lasach, część 1. Studia i Materiały Centrum Edukacji Przyrodniczo-Leśnej R.9. Zesz. 2/3 (16): 59-69.

ZELENÝ, D., TICHÝ, L. 2006. Unconstrained ordinations in Juice. Institute of Botany and Zoology. Masaryk University, Brno. http://sci.muni.cz/botany/zeleny/ ordination. 